\title{
Regulation indicators of sustainable development of the Volga region
}

\author{
Sergey Mikhailovich Nikonorov \\ Lomonosov Moscow State University \\ Faculty of Economics \\ Moscow, Russia \\ nico.73@mail.ru
}

\author{
Sergey Nikolaevich Kirillov \\ Lomonosov Moscow State University \\ Faculty of Geography \\ Moscow, Russia \\ eco-msu@mail.ru
}

\author{
Sofya Valentinovna Solovyova \\ Lomonosov Moscow State University \\ Faculty of Economics \\ Moscow, Russia \\ solovyevasv@gmail.com
}

\begin{abstract}
The paper examines the ecological and economic aspects of managing the sustainable development of the Volga regions. A group of developed regions of the Volga region with a diversified economy is singled out, which rely on the manufacturing industry and on the extractive industry, which is reflected in the nature of the formation of the gross regional product and affects the values of indices of sustainable development. The characteristic for some regions of the Volga region is given according to their development in accordance with the ecological-economic index, the human development index and the index of the ecological footprint. In the sustainable development strategies of the key regions of the Volga region a comparison is made between environmental, social and economic development indicators. There is insufficient attention to environmental indicators. Competitive characteristics of the regions of the Volga region are reflected mainly through the prism of the human development index and also use insufficient data on the state of the environment and the use of natural resources. Integral socio-ecological and economic assessment of developed regions of the Volga region was made on three key indicators of sustainable development. The raw nature of the economic development of the Volga regions, characterized by a high dependence on the extraction of mineral resources, not only does not correspond to the idea of modernizing the economy, but also exacerbates the complex ecological situation.
\end{abstract}

Keywords - economic growth, regional development, quality of life, sustainability, ecological and economic index, Volga region

\section{INTRODUCTION}

Significant experience has been accumulated in the world and domestic science and practice on the development of criteria, indices and indicators of sustainable development in the regional context. The most productive is the construction of integral indices, which aggregate environmental-economic, socio-economic, environmental indicators to assess the degree of sustainability of socio-economic development of regions. A more free form allows the construction of a system of indicators, each of which reflects individual aspects of sustainable development.
Indices and indicators of sustainable development in the regional context perform a number of functions: setting goals for the development of strategies for long-term and mediumterm regional development; forecasting the effect of sustainable nature management policies; monitoring of achievement of goals and objectives of improving the quality of life of the population and evaluation of results; evaluation of the effectiveness of programs and strategies; interregional comparisons; attraction of investments into the economy of the region; the formation of programs for the best use of resources.

It is possible to distinguish three integral indexes, welldeveloped both internationally and in the Russian context, which characterize the sustainability of development from various sides. The index of "adjusted net savings", theoretically and practically developed at the World Bank, is highly integrated. The index is calculated annually for all countries of the world [1]. The ecological and economic index was developed and calculated for the regions of Russia based on the concept and methodology for calculating the World Bank's index of adjusted net savings ("genuine savings"). The calculations showed a significant regional differentiation of the index [2].

The Human Development Index (HDI), developed and annually calculated since 1990 in the framework of the United Nations Development Program, reflects the social side of sustainable development. Subsequently, it began to be calculated for the regions of the Russian Federation. In Russia, the Human Development Index is calculated for the National Reports of the United Nations Development Program on Human Development since 1997 [3].

"Ecological Footprint" as an ecological integral index was developed by the World Wildlife Fund. The index is adapted for Russia, calculated by regional subjects of the Russian Federation [4]. 


\section{MATERIALS AND METHODS}

We propose to use the indicator of "genuine savings" in accordance with one of the integral indicators of sustainable development. The indicator of genuine savings characterizes the rate of accumulation of national savings after proper consideration of depletion of natural resources and damage from environmental pollution. The indicator is the result of correction of gross domestic savings. Compared with traditional macroeconomic indicators, genuine savings include the necessary accounting of natural capital, improved data and methods of calculation, and the accounting of human resources.

Comparison of Russian regions by indices is most significant for regions close in economic level and production structure. Regional economy is characterized by regional inequality in Russia. Russian regions are characterized by very high differentiation in terms of their development level, related to their industry specialization, which is largely determined by historical preconditions and features of industrial development in the Soviet years. On the one hand, the export orientation of the Republic of Tatarstan and the Samara region extracting oil and gas is set geographically and historically; on the other hand, the industrial orientation of such regions as the Nizhny Novgorod region was determined by the features of the country's development during the industrialization of the 1930s. This suggests that, in a number of cases, the characteristics of the sustainability of the ecological development of certain regions are de facto determined.

This circumstance, of course, cannot be extended to all regions. The degree of the region's determinism on one or another ecological path of development has some measure, and in its development trajectory each region has a certain degree of freedom determined by federal and regional economic policies.

Nevertheless, due to significant differences in the regions, groups of the same type regions were identified according to the prerequisites for the development of regions to compare them according to the level of economic development and branch specificity. As a result, all regions of the Russian Federation were compared. The regions were compared in the framework of homogeneous groups, taking into account the industry specialization of the economies of the subjects of the Russian Federation. When the regions were divided into groups, the principles and approaches proposed in the book "The Russian Regions: the Economic Crisis and the Problems of Modernization" were taken as a basis [5].

The Ecological Footprint reflects the assessment of the area of bioproductive land on the planet and the measurement of human needs in these bioproductive lands.

The Ecological Footprint is calculated in global hectares (global hectares per capita) and shows the number of conditional hectares of the territory necessary to ensure human life with the current level of consumption and utilization of waste from its life. The index is calculated as part of the annual report of the World Wildlife Fund. The index is adapted for the Russian Federation and is calculated by regions of Russia from 2012.

Comparison of the regions of the Volga region on integrated indices: ecological and economic, ecological footprint and human development gives an idea of the heterogeneity of territorial development and the need to use these three indices to obtain an objective situation of the regional development. The main publications on sustainable development for the regions of the Russian Federation came out in 2016 and reflect the situation for 2012-2014. The use of indicators for regulating sustainable development is acceptable, since they are sufficiently inertial.

\section{RESULTS AND DISCUSSION}

All subjects of the Russian Federation can be divided into four groups: financial and economic centers; export-oriented regions; industrial regions; agrarian and industrial regions. The methodology for determining clusters and the distribution of regions by groups are taken from the synthetic classification of Russian regions [6]. In accordance with the new version of the synthetic classification, the regions of Russia are divided into 9 types, grouped into 4 groups:

- $\quad$ highly developed regions (leading regions): financial and economic centers (capitals), raw materials exportoriented;

developed regions: with a diversified economy, relied on the manufacturing industry, relied on the extractive industry;

- medium-developed regions: industrial-agrarian,
agrarian-industrial;

- less developed regions: less developed raw materials, less developed agrarian.

In the Volga region are concentrated industrial-agrarian and agrarian-industrial regions. The Republic of Tatarstan, the Nizhny Novgorod Region and the Samara Region belong to a group of developed regions with a diversified economy. The Republic of Mari El, the Chuvash Republic, the Saratov Region and the Ulyanovsk Region are classified as mediumdeveloped agro-industrial regions. The most significant comparison of regions by indices from one group: the Republic of Tatarstan, the Nizhny Novgorod region and the Samara region.

Differences between regions within a single group of developed regions with a diversified economy are great. The ecological and economic index (EEI) varies by the regions in the Volga region.

The Nizhny Novgorod region with the high accumulation rate $(27.4 \% \mathrm{GRP})$ and the lack of mineral resources, investing in education, nature protection measures and protected areas, has the highest EEI index, 45.99\%.

The Republic of Tatarstan, with a higher accumulation rate (33.6\% GRP), but depletion of fuel and energy resources and associated pollution of the environment (294 thousand tons of air emissions), has more than twice smaller the EEI index, $19.91 \%$. 
In the Samara region, with the rate of accumulation of $28.6 \%$ of GRP, the depletion of fuel and energy resources and associated pollution of the environment (266 thousand tons of air emissions), the EEI index was $9.38 \%$ (Table 1).

At the core of the economy of the Republic of Tatarstan and the Samara region is the fuel and energy resource sector. Since the index is designed to reflect the depletion of natural capital in the event of a lack of its replacement, this determines the regional dispersion of the index values.

TABLE I. COMPARISON OF THE REGIONS OF THE VOLGA REGION ON INTEGRATED INDEXES

\begin{tabular}{|c|c|c|c|}
\hline $\begin{array}{c}\text { Subject of the } \\
\text { Federation }\end{array}$ & $\begin{array}{c}\text { EEI, } \\
\text { \% GRP }\end{array}$ & $\begin{array}{c}\text { EF, } \\
\text { glob. ha / } \\
\text { person }\end{array}$ & HDI \\
\hline $\begin{array}{c}\text { Nizhny Novgorod } \\
\text { Region }\end{array}$ & 45,99 & 4,78 & 0,854 \\
\hline Republic of Tatarstan & 19,91 & 4,97 & 0,894 \\
\hline Samara Region & 9,38 & 5,59 & 0,865 \\
\hline
\end{tabular}

There is a clear correlation between the EEI index and the Ecological Footprint (EF) for a group of developed regions with a diversified economy. The Nizhny Novgorod region at high genuine savings of 45.99 has the lowest Ecological Footprint of 4.78. The Samara region with a low genuine saving of 9.38 has the highest Ecological Footprint of 5.59. A region with more sustainable development has less impact on natural and ecological conditions and forms a smaller Ecological Footprint.

The ranking of regions by the Human Development Index (HDI) gives a different sequence compared to the Ecological and Economic Index (EEI). According to the ecological and economic index, the first place is occupied by the Nizhny Novgorod region, according to the HDI - the Republic of Tatarstan. This is not surprising, given the ideology of the EEI index to reflect damage to natural resources and the environment.

Regional differentiation of the integral HDI index is particularly noticeable difference for a group of developed regions with a diversified economy. The table shows regional differences in the values of the HDI and its components in 2014. Leader of the rating, compiled by the HDI, among the Volga regions in 2014 remained the Republic of Tatarstan at the expense of the highest in the Volga region per capita GRP $(\$ 30,500)$, as well as indicators of life expectancy and development of the education system. The Samara region also ranks second at the expense of the per capita GRP $(\$ 23,000)$, while the life expectancy is at a level comparable to or lower than in other regions of the Volga region. The Nizhniy Novgorod region (0.854) had a backward position due to the low GRP per capita.

It should be emphasized that the key role in the ranking of the regions of the Volga region was the ratio of GRP per capita. The HDI is more of a socio-economic indicator and needs an environmental adjustment. Let's try to find out the place of competitiveness of the Volga regions on the basis of the human development index (Table 2).
TABLE II. THE INDEX OF HUMAN DEVELOPMENT BY REGIONS OF THE VOLGA REGION

\begin{tabular}{|c|c|c|c|c|}
\hline $\begin{array}{l}\text { Subject of the } \\
\text { Federation }\end{array}$ & $\begin{array}{c}\text { Per } \\
\text { capita } \\
\text { GRP, } \\
\text { USD } \\
\text { PPP } \\
\end{array}$ & $\begin{array}{c}\text { Life } \\
\text { expec- } \\
\text { tancy, } \\
\text { years }\end{array}$ & $\begin{array}{c}\text { Educa- } \\
\text { tion } \\
\text { index }\end{array}$ & HDI \\
\hline Republic of Tatarstan & 30467 & 72,17 & 0,942 & 0,894 \\
\hline Samara Region & 23082 & 69,63 & 0,942 & 0,865 \\
\hline $\begin{array}{c}\text { Nizhny Novgorod } \\
\text { Region }\end{array}$ & 20156 & 69,53 & 0,933 & 0,854 \\
\hline
\end{tabular}

Most development programs in the regions of the Volga region have been targeted at achieving socially oriented objectives. In the Strategy of Social and Economic Development of the Republic of Tatarstan until 2030, Tatarstan-2030 pays special attention to "the accumulation of human capital as a key asset" for achieving high quality of life and efficient use of natural resources "on the basis of sustainable development principles". However, the indicators of achievement of the set goals in the regional development programs are represented by a set of disparate traditional indicators, mainly economic and social (life expectancy, average monthly wages, etc.), and GRP is the key indicator of the region's development. The program includes a rating, but exclusively investment attractiveness, where the Republic of Tatarstan consistently occupies high places.

Strategy-2030 of the Samara Region contains targeted directions in the field of nature management: the introduction of resource and energy saving technologies, the best available technologies for stabilizing electricity consumption in conditions of growth in industrial production; production of fuel meeting international environmental standards; alternative energy sources; modernization of communal infrastructure; waste management; creation of green zones of cities. However, the quantitative standard has only one direction: utilization of natural associated gas up to $95 \%$.

The authors analyzed the indicators from the standpoint of their compliance with the adopted goals in long-term strategies for the development of the Volga regions. The socio-economic strategies of the regions as a whole cover three components of sustainable development. At the same time, a number of indicators, which have mainly an environmental focus, have not been reflected in the strategies. Thus, environmental indicators are almost not reflected in the directions of activities contained in the strategies of the regions.

In the current conditions of regional development of Russia (85 subjects of the Russian Federation), due to the heterogeneity of the subjects themselves, their different economic, natural and social development potentials, on the one hand, and due to rapid changes in the social, economic and technological structures of the system, on the other hand, the application Western models are not justified. This is shown by attempts to determine the indices of strong and 
weak stability obtained on the basis of certain assumptions for some regions of Russia.

We need a more flexible and adaptive model of regional development, based on volatile and indicative planning, using the proportions of strategic changes. The ecological and economic index for the regions of the Volga region is as follows (Table 3 ).

TABLE III. RANGING OF THE REGIONS OF THE VOLGA REGION ON THE ECOLOGICAL AND ECONOMIC INDEX

\begin{tabular}{|c|l|c|}
\hline $\begin{array}{c}\text { Region } \\
\text { number in } \\
\text { the Volga } \\
\text { region }\end{array}$ & Region & $\begin{array}{c}\text { Ecological and } \\
\text { economic index, } \\
\text { in \% to GRP }\end{array}$ \\
\hline 3 & Ulyanovsk region & 39,79 \\
\hline 8 & Saratov region & 19,98 \\
\hline 9 & Republic of Tatarstan & 19,91 \\
\hline 12 & Samara Region & 9,38 \\
\hline b. & Source: Ecological and Economic Index of Russian Regions / S.N. Bobylev, S.V.
\end{tabular}
Solovyova et al. - Moscow: WWF of Russia, 2012.

The following indicators were taken to calculate this complex index: 1) gross fixed capital formation; 2) investments in fixed assets; 3 ) depletion of natural resources; 4) damage caused by environmental pollution; 5) expenses for the development of human capital; 6) costs of environmental protection; 7) specially protected natural areas [2].

\section{CONCLUSION}

For the Volga regions it is very important to balance the individual components of development: economic income, education, life expectancy, ecological situation [7]. The definition of a lagging component allows us to concentrate resources and address the priority tasks of sustainable development, and not just send subsidies and transfers to the regions. The raw nature of the economic development of the Volga regions, characterized by a high dependence on the extraction of mineral resources, not only does not correspond to the idea of modernizing the economy, but also exacerbates the complex ecological situation in the regions. The solution to the problem is possible through the development of a lowcarbon economy, the use of renewable energy sources and a significant reduction in resource and energy losses [8].

It should be recognized that now Russian strategic documents on the development of the regions look rather onesided, poorly take into account the state of the environment.
Therefore, when developing long-term documents for the development of the regions of the Volga region, it seems important to integrate the indices in question in general or in a disaggregated form. In particular, it is advisable for the strategic development directions for the period to 2030 to agree on indices, priorities and target areas for long-term development of the regions.

\section{Acknowledgment}

The study was carried out with the financial support of the Russian Foundation for Basic Research, project No. 17-0200773 "Theoretical and methodological foundations for sustainable development of Russian regions (on the example of the Volga region)".

\section{References}

[1] The Little Green Data Book. World Bank. 2016. 237 p.

[2] Bobylev S.N., Minakov V.S., Solov'eva S.V., Tret'jakov V.V. Economic environmental index of Russian regions [Jekologo-jekonomicheskij indeks regionov RF]. Moscow: WWF Russia, RIA Novosti. 2012. 147 p.

[3] Human development report for the Russian Federation in 2016 [Doklad o chelovecheskom razvitii v Rossijskoj Federacii za 2016 god] / Eds. S. N. Bobylev and L.M. Grigor'ev. M.: Analytical center for the Government of the Russian Federation, 2016. 298 p.

[4] Ecological footprint of the Russian regions - 2016 [Jekologicheskj sled sub'ektov Rossijskoj Federacii] / Ed. P.A. Вoev и D.L. Burenko. M.: WWF Russia, 2016. 112 p.

[5] Russian regions: the economic crisis and the problems of modernization [Rossijskie regiony: ehkonomicheskij krizis i problemy modernizatsii] / Eds. L.M. Grigorieva, N.V. Zubarevich, G.R. Khasaeva - Moscow: TEIS, 2011. $357 \mathrm{p}$.

[6] Goliashev A.V., Grigoriev L.M. Types of Russian regions: sustainability and shifts in 2003-2013. Analytical report [Tipy rossijskikh regionov: ustojchivost' i sdvigi v 2003-2013 godakh. Analiticheskij doklad]. Moscow, 2014. 47 p.

[7] Bobylev S.N. Sustainable development: methodology and measurement methods [Ustojchivoe razvitie: metodologija i metodiki izmerenija] // S.N. Bobylev, N.V. Zubarevich, S.V. Solov'eva, Yu.S. Vlasov. M.: Economika, 2011.358 p.

[8] Towards sustainable development of Russia. Green economy and modernisation. Ecological-economical principles of sustainable development [ $\mathrm{Na}$ puti $\mathrm{k}$ ustojchivomu razvitiju Rossii. «Zelenaja» jekonomika i modernizacija. Jekologo-jekonomicheskie osnovy ustojchivogo razvitija] / Ed. V.M. Zakharov. M.: Institute of sustainable development, 2012. $90 \mathrm{p}$. 